\title{
Separation of Flue-Gas Scrubber Sludge into Marketable Products
}

\author{
Second Year, Third Quarterly Technical Progress Report \\ Performance Period: 3/1/95 to 5/31/95 (Quarter \#7) \\ Principal Investigators: \\ S. K. Kawatra and T. C. Eisele \\ Graduate Student: \\ Kyle Shoop \\ Work Performed Under Contract No. \\ DE-FG22-93PC93214 \\ For the \\ U.S. Department of Energy \\ Pittsburgh Energy Technology Center \\ Pittsburgh, Pennsylvania \\ By \\ Michigan Technological University \\ Department of Metallurgical and Materials Engineering \\ Michigan Technological University \\ 1400 Townsend Drive \\ Houghton, Michigan 49931-1295 \\ D.O.E. Project Manager: \\ Robert W. Gross \\ Morgantown Energy Technology Center
}

June, 1995

"U. S. DOE. Patent Clearance is not required prior to the publication of this document."

\section{DISCLAIMER}

This report was prepared as an account of work sponsored by an agency of the United States Government. Neither the United States Government nor any agency thereof, nor any of their employees, makes any warranty, express or implied, or assumes any legal liability or responsibility for the accuracy, completeness, or usefulness of any information, apparatus, product, or process disclosed, or represents that its use would not infringe privately owned rights. Reference herein to any specific commercial product, process, or service by trade name, trademark, manufacturer, or otherwise does not necessarily constitute or imply its endorsement, recommendation, or favoring by the United States Government or any agency thereof. The views and opinions of authors expressed herein do not necessarily state or reflect those of the United States Government or any agency thereof.

8

$\underline{2}$

$\infty$

$4=$

$=17$

5

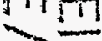

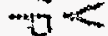

r17 ITI

$-1$ 


\section{Introduction}

To reduce their sulfur emissions, many coal-fired electric power plants use wet flue-gas scrubbers. These scrubbers convert sulfur oxides into solid sulfate and sulfite sludge, which must then be disposed of. This sludge is a result of reacting limestone with sulfur dioxide to precipitate calcium sulfite and calcium sulfate. It consists of calcium sulfite $\left(\mathrm{CaSO}_{3} \bullet 0.5 \mathrm{H}_{2} \mathrm{O}\right)$, gypsum $\left(\mathrm{CaSO}_{4} \cdot 2 \mathrm{H}_{2} \mathrm{O}\right)$, and unreacted limestone $\left(\mathrm{CaCO}_{3}\right)$ or lime $\left(\mathrm{Ca}(\mathrm{OH})_{2}\right)$, with miscellaneous objectionable impurities such as iron oxides, silica, and magnesium, sodium, and potassium oxides or salts (Goldstein, 1990). These impurities prevent many sludges from being utilized as a replacement for natural gypsum, and as a result they must be disposed of in landfills, which presents a serious disposal problem (Carnahan, 1993).

This project is studying the characteristics of flue-gas scrubber sludges from several sources. Knowledge of scrubber sludge characteristics is necessary for the development of purification technologies which will make it possible to directly utilize scrubber sludges rather than landfilling them. This purification will consist of minimal-reagent froth flotation, using the surface properties of the particles of unreacted limestone to remove them and their associated impurities from the material, leaving a purified calcium sulfite/gypsum product.

The objectives of this project are to:

1 Investigate properties of scrubber sludge that will control its behavior in separation processes, and determine how the surface properties of the sludge particles change as the conditions in the solution change.

2 Examine the ability of various froth-flotation processes to separate the various components based on differences in their surface chemistry.

3 Determine methods for accomplishing the separation without adding additional chemical hazards to the environment.

These objectives will be accomplished by analysis of the composition and flotation behavior of scrubber sludges from various sources. This will lead to the development of a novel application of froth flotation to produce a clean separation with a minimum of reagents. Analysis of the sludge will be carried out using both standard analytical techniques, and specialized methods developed for this purpose at Michigan Technological University.

Since the surface chemistry of the solid particles in scrubber sludge is not well known, this project will provide a good deal of basic information which is not currently available from any source. This information is critical to both the purification and the effective utilization of the sludge, since seemingly small changes in surface chemistry can have a disproportionate effect on the overall properties of the material.

Quarterly Report \#1 described the collection and preparation of sludge samples from three coal-fired power plants, the preparation of these samples for use in the planned studies, and the results of their characterization by X-ray diffraction. In Quarterly Report \#2, initial froth flotation studies using conventional flotation equipment were summarized. These flotation studies determined that a good separation of limestone from the sludge could be 
made using a cationic collector. A reverse flotation process was used, with the sinks product being the purified material, and the froth product being the rejected impurities. Quarterly report \#3 described the results of column flotation of the scrubber sludge. It was determined that the column provided better removal of unreacted limestone than was possible with conventional flotation, due to its inherently higher selectivity. However, limestone content in the useful product was still too high for industrial use. Initial studies of the zeta potentials of the most important species found in scrubber sludge were also described. Quarterly report \#4 continued the zeta potential studies of the major components in the scrubber sludge. These studies included the effect on zeta potential when the following factors were varied: $\mathrm{pH}$, dissolved salts, and concentration of collector dosage. Quarterly report \#5 described the conclusion of the zeta potential work. This investigation included the determination of the point of zero charge for all the major components in scrubber sludge (Calcium Sulfite, Calcium Sulfate, and Calcium Carbonate). Quarterly report \#6 investigated the optimum frother and frother dosages to use for the flotation of limestone. This optimization was needed because previous flotation tests were unable to provide a clean enough product for industrial use. Several frothers were studied: DF200, DF250, DF400, and DF1012 at various dosages. DF200 proved to be the most selective of the frothers studied for the removal of limestone.

In the seventh quarter progress continued on the optimization of operating parameters for the flotation of limestone, $\mathrm{CaCO}_{3}$. A new collector, S701, developed by Dow Chemical Company, Midland, MI, and a gypsum depressant, were investigated. The gypsum depressant used was gelatin, a water soluble protein (Sutherland and Wark, 1955). A new two- inch hydrocyclone test rig was also designed and constructed during this quarter. Further work was also done on the characterizations of the limestone and coal used at the Plant A power station.

\section{Progress During the Seventh Quarter}

\section{Hydrocyclone Test Rig}

Hydrocycloning was implemented because froth flotation could not remove enough of the impurities to make the gypsum a useful product. There are two different types of hydrocyclones, water-only and conventional cyclones. Water-only cyclones separate on the basis of density, where as conventional cyclones separate on the basis of size. The difference in the density of gypsum and limestone made water-only cyclone a reasonable choice. Hydrocycloning served two purposes. The first was to remove ball mill chips and coarse limestone. The second was the ability of the hydrocyclone to scrub the surface of the limestone which allows the limestone to become partially hydrophobic and float by itself. Therefore a two-inch hydrocyclone test rig was designed and constructed, see Figure 1. The funding for purchasing the progressive cavity pump and the two horsepower variable speed motor was provided by Dow Chemical Company, Midland, MI. This test rig was designed for ease of sample collection, which includes the sample of the overflow, underflow, and feed material. The test rig was also designed so small samples could be cycloned, which helps save on the amount of sample needed for each test. 


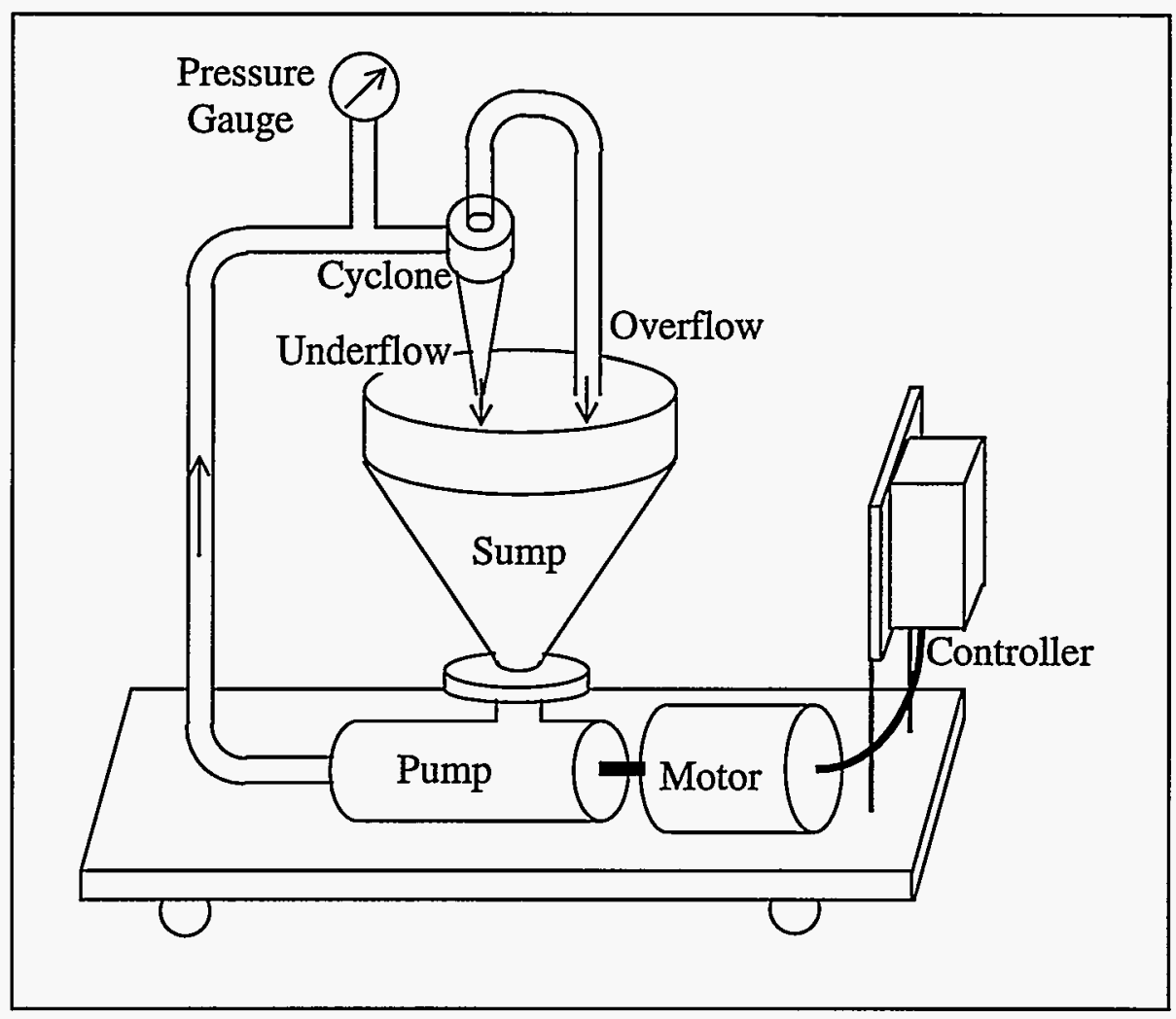

Figure 1. Schematic of two-inch hydrocyclone test rig. The rig consists of a progressive cavity pump connected to a two horsepower variable speed motor. The motor controller was wired for three phase power, and the whole test rig was made portable with the addition of wheels to the base plate. The sump was designed to hold up to 18 liters of slurry. The piping was made from $3 / 4$ inch PVC pipe, and a pressure gauge which ranges from 0 to 30 psi was also attached. The test rig was also designed for quick and easy installation and cleaning of various hydrocyclones. 


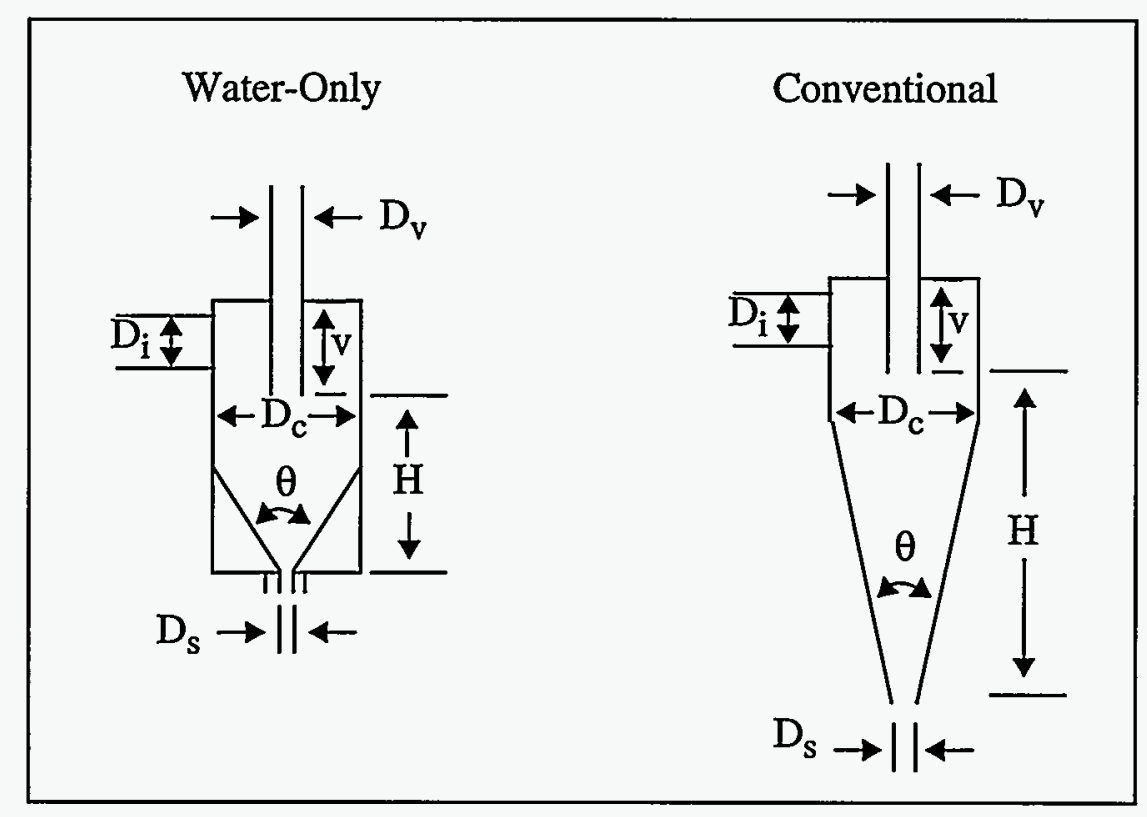

Table 1. Possible combination of the hydrocyclones that can be used for the two-inch hydrocyclone test rig.

\begin{tabular}{|l|c|c|c|c|c|c|c|}
\hline & $\begin{array}{c}\mathrm{D}_{\mathrm{i}} \\
(\mathrm{mm})\end{array}$ & $\begin{array}{c}\mathrm{D}_{\mathrm{c}} \\
(\mathrm{mm})\end{array}$ & $\begin{array}{c}\mathrm{D}_{\mathrm{v}} \\
(\mathrm{mm})\end{array}$ & $\begin{array}{c}\mathrm{D}_{\mathrm{s}} \\
(\mathrm{mm})\end{array}$ & $\begin{array}{c}\mathrm{v} \\
(\mathrm{mm})\end{array}$ & $\begin{array}{c}\mathrm{H} \\
(\mathrm{mm})\end{array}$ & $\begin{array}{c}\mathrm{q} \\
(\mathrm{deg} .)\end{array}$ \\
\hline \hline Water-Only & $6 \times 10$ & 51 & 14 & 6 & 25 & 27 & 90 \\
& $6 \times 8$ & 51 & 11 & 5 & 25 & 29 & 90 \\
& $6 \times 6$ & 51 & 8 & 3 & 22 & 30 & 90 \\
\hline Conventional & $\begin{array}{l}\text { same as } \\
\text { above }\end{array}$ & 51 & $\begin{array}{l}\text { same as } \\
\text { above }\end{array}$ & 10 & $\begin{array}{l}\text { same as } \\
\text { above }\end{array}$ & 311 & 6.6 \\
\hline
\end{tabular}

The two types of hydrocyclones, conventional cyclone and a water-only cyclone, can also be used in this test rig, see Table 1 for various dimensional combinations possible for of each type of hydrocyclone. The installation and the changing of different hydrocyclones can be done in a short period of time, therefore optimizing experimentation time. The hydrocyclones are on loan to us from the Institute of Material Processing, MTU. 


\section{Hydrocyclone Experiments}

A water-only cyclone was selected because of the differences in the density of limestone (2.7345 $\left.+/-0.003 \mathrm{~g} / \mathrm{cm}^{3}\right)$ and gypsum $\left(2.305 \mathrm{~g} / \mathrm{cm}^{3}\right)$. The cyclone parameters consisted of a $6 \mathrm{~mm}$ spigot, an $11 \mathrm{~mm}$ vortex finder, and a pressure of $15 \mathrm{psi}$. The feed material was a scrubber sludge sample collected from the Plant A power station. The initial feed assay was $5.15+1-0.09 \% \mathrm{CaCO}_{3}$. A total of $3,220.9$ grams of sludge was cycloned at $5 \%$ solids by weight. The two cyclone products, overflow and underflow, were then weighed wet and then dried at $45^{\circ} \mathrm{C}$. The overflow was the useful product because it contained less limestone, $\mathrm{CaCO}_{3}$. The overflow product contained 3.03 $+1-0.09 \% \mathrm{CaCO}_{3}$ and was $69 \%$ of the total weight cycloned. This overflow product was then mixed and split for material to be used in froth flotation experiments.

\section{Froth Flotation Experiments}

The procedure used for froth flotation experiments was consistent with the procedure given in progress report \#6, where a conventional flotation cell with automated paddles was used. This is a reverse flotation process where the limestone, one of the impurities, is being floated and the gypsum, a valuable product, reports to the sinks. Initial tests duplicated optimal frother conditions that were reported in the last progress report. Table 2 contains the reagents and test conditions used for flotation experiments in this quarter. An acceptable grade of product for the wallboard industry, less than $2.0 \% \mathrm{CaCO}_{3}$, (Van der Brugghen and Koppins-Odink, 1989) was obtained with a dosage of $0.2 \mathrm{Kg} / \mathrm{mt}$ of DF 200, however the recovery was approximately $64 \%$ by weight. This led to experimentation with S701, a newly developed Dow Chemical Collector, and gelatin, which acts as a gypsum depressant. There have been several gypsum depressants reported in the literature (Weiss, 1985). These gypsum depressants include: sulfuric acid, gelatin, or tannic acid. Gelatin was selected because it is not an acid and therefore would not dissolve the limestone. The work with the S701 and gelatin did not have much effect on improving the grade or recovery of the gypsum, but this work is still in its infancy and future work is planned for the next quarter. 
Table 2. Flotation results obtained after the material was cycloned in a two- inch water-only cyclone. The feed assay was $3.03 \%+/-0.09 \mathrm{CaCO}_{3}$.

\begin{tabular}{|c|c|c|c|}
\hline Reagents & $\begin{array}{c}\text { Dosage } \\
(\mathrm{Kg} / \mathrm{mt})\end{array}$ & $\begin{array}{c}\text { \% Wt.Recovery of } \\
\text { Valuable Product } \\
\text { after Flotation }\end{array}$ & $\begin{array}{c}\% \mathrm{CaCO}_{3} \text { in } \\
\text { Valuable Product }\end{array}$ \\
\hline \hline DF 200 & 0.2 & 63.3 & $1.64+/-0.04$ \\
\hline DF 200 & 0.2 & 64.3 & $1.75+/-0.04$ \\
\hline $\begin{array}{c}\text { DF 200 } \\
\text { S701 }\end{array}$ & 0.2 & 63.8 & $1.62+/-0.01$ \\
\hline DF 200 & 0.067 & 85.5 & $2.26+/-0.07$ \\
\hline DF 200 & 0.2 & 43.0 & $1.63+/-0.03$ \\
Gelatin & 0.2 & 87.0 & $2.30+/-0.06$ \\
\hline DF 200 & 0.05 & & \\
Gelatin & 0.05 & &
\end{tabular}

\section{Characterization of Limestone and Coal used at Plant A}

Samples of the limestone used in the wet flue-gas scrubber and the coal burned at the Plant A power station were collected and analyzed. This was done to gain additional information on the flue-gas scrubbing process and to determine some of the physical properties of the impurities in wet flue-gas scrubber sludge. The limestone is first ground in a ball mill before it is pumped into the wet flue-gas scrubber. The size distribution of the ground limestone is give in Figure 2. This size distribution was determined by laser diffraction. The ground slurry enters the scrubber at $26 \%$ solids by weight, has a $\mathrm{pH}$ of 8.02 , density of $2.7345+/-0.003$ (measured by an AccuPyc 1330 Pycnometer), and contained $96.88+/-$ $0.03 \% \mathrm{CaCO}_{3}$ (measured by TGA).

The coal sample that was collected contained $3.48+/-0.023 \%$ sulfur, $37.3+/-0.07$ volatile matter, $12.41+/-0.22$ ash, and $50.30+/-0.20$ fixed carbon. The volatile matter, ash, and fixed carbon were measured on a dry basis. 
Size Distribution of Limestone used for Plant A Scrubber

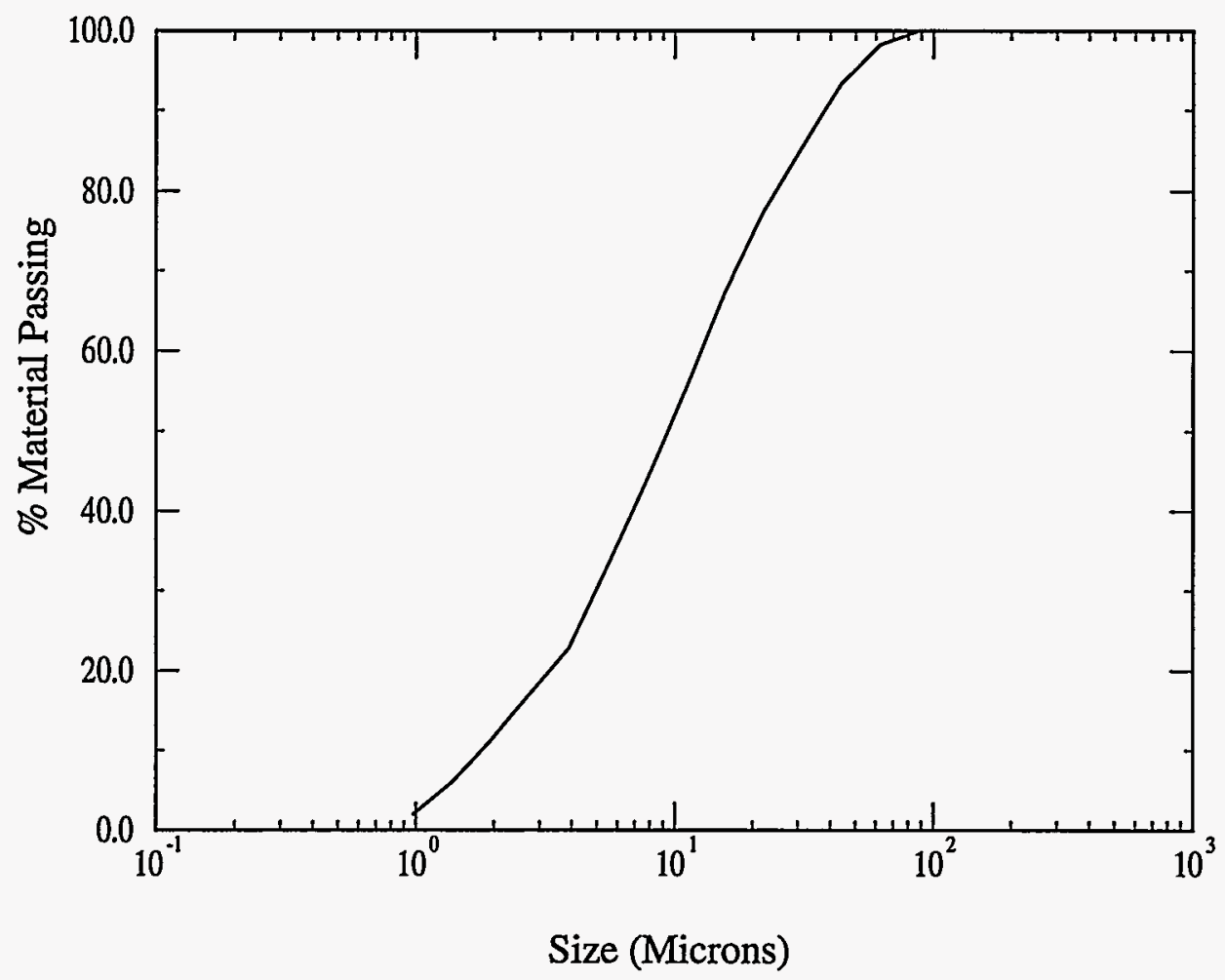

Figure 2. The size distribution of the ground limestone before it enters the wet flue-gas scrubber at Plant A. The size distribution was determined by laser diffraction. The density of the sample was $2.7345 \mathrm{~g} / \mathrm{cm}^{3}+/-0.003$, and was $96.88 \%+/-0.03 \mathrm{CaCO}_{3}$. Densities were determined by using an AccuPyc 1330 Pycnometer and\% $\mathrm{CaCO}_{3}$ was determined by Thermogravimetric Analysis (TGA).

\section{Plans for the Eighth Quarter}

Work will be continued with the two-inch hydrocyclone with goals of optimizing the separation of calcium carbonate and gypsum. This will be done by varying the parameters of the water-only cyclone. Initial parameter variation will be the pressure of the feed stream and\% solids by weight of the feed slurry. The pressure will be varied from $5-20 \mathrm{psi}$ at 5 psi intervals, and the $\%$ solids will also be varied from $5-20 \%$ solids by weight at intervals of $5 \%$. The optimal results from the hydrocyclone test, overflow product with low $\mathrm{CaCO}_{3}$ and good recovery, will then be the feed material for froth flotation experiments.

Froth flotation experiments will focus on meeting the desirable grade for clean gypsum, less than $2.0 \% \mathrm{CaCO}_{3}$ (Van der Brugghen and Koppins-Odink, 1989), and still maintain a good recovery. Emphasis will be placed on using newly developed collectors and gypsum depressants. This work will be done using a conventional flotation machine which has the automated paddles and at the natural $\mathrm{pH}$ of the scrubber sludge slurry. 
Carnahan, R.,1993. personal communication, U.S Gypsum.

Goldstein, G., 1990. "Scrubbing Coal for Emission Control," Mechanical Engineering, Vol. 112, pp60-65.

Sutherland, K.L. and Wark, I.W., 1955. Principles of Flotation, Australasian Institute of Mining and Metallurgy, Inc., Melbourne, pp 41.

Van der Brugghen, F. W., and Koppins-Odink,J.M., 1989, "Flue Gas Cleaning in Power Stations in the Netherlands," Proceedings: First Combined Flue Gas Desulfurization and Dry SO2 Control Symposium, Electric Power Research Institute, paper 1-5, pp1-69 to $1-94$

Weiss, N. L. (editor), 1985. SME Mineral Processing Handbook, American Institute of Mining, Metallurgical, and Petroleum Engineers, New York, pp 29-12 